\title{
On the identity of Pardosa taczanowskii (Thorell) (Araneae: Lycosidae)
}

\section{О тождестве Pardosa taczanowskii (Thorell) (Araneae: Lycosidae)}

\author{
Torbjörn Kronestedt \\ Т. КрунестеАт
}

Department of Entomology, Swedish Museum of Natural History Box 50007, SE-104 05 Stockholm, Sweden. E-mail: torbjorn.kronestedt@nrm.se

\author{
KEY WORDS: taxonomy, Siberia, Pardosa chionophila, new synonym. \\ КЛЮЧЕВЫЕ СЛОВА: таксономия, Сибирь, Pardosa chionophila, новый синоним.
}

ABSTRACT. A study of the type material of $L y$ cosa (now Pardosa) taczanowskii Thorell, 1875, originally said to have been collected in Poland but apparently of Asian origin, has revealed that it is conspecific with Pardosa chionophila L. Koch, 1879. Thorell's description of male $P$. taczanowskii fits the single male type specimen (here designated as lectotype) which is conspecific with a male of $P$. chionophila from the type locality of the latter species. Pardosa chionophila L. Koch, 1879, syn.n. is placed as a junior synonym to $P$. taczanowskii. The epigyne of $P$. jeniseica Eskov et Marusik, 1995, a species in the taczanowskii group, is depicted for the first time.

PЕЗЮМЕ. Изучение типового материала Lycosa (теперь Pardosa) taczanowskii Thorell, 1875, описанного из Польши, но, предположительно, собранного в Азии, показало, что этот вид не отличается от Pardosa chionophila L. Koch, 1879. Описание самца P. taczanowskii, приведённое Тореллем, однозначно подходит к единственному самцу из типовой серии (выделен мною в качестве лектотипа). Лектотип не отличается от самца $P$. chionophila, собранного в типовой местности. Соответственно, Pardosa chionophila L. Koch, 1879, syn.n. признаётся младшим синонимом $P$. taczanowskii. Эпигина $P$. jeniseica Eskov et Marusik, 1995, вида, принадлежащего к группе taczanowskii, проиллюстрирована впервые.

\section{Introduction}

Two out of numerous species described in 1875 by Tamerlan Thorell [Thorell, 1875a], viz. Pardosa (sub Lycosa) taczanowskii and Alopecosa (sub Tarentula) edax, were based on material which he received from Władysław Taczanowski, contemporary curator at the Zoological Cabinet of Imperial Warsaw University. Taczanowski's main interest was ornithology, but he also dealt with spiders from different parts of the world. Apart from participating in an expedition to Algeria, Taczanowski did not undertake any travels outside Europe [Wikipedia, 2012]. He was, however, very active in arranging for material to be sent from various collectors to the museum in Warsaw. In arachnology, Taczanowski is mainly known for his papers on spiders from French Guyana and Peru [Prószyński, 2001].

In the original descriptions [Thorell, 1875a], both of the abovementioned species were said to have been collected in Warsaw, Poland, but no additional material has ever been found in that country. Both species were catalogued as Polish in Prószyński \& Staręga [1971] but Staręga later [Staręga, 1983] stated that they probably are of Asian origin, maybe from Mongolia. Comparison of the male holotype of Alopecosa edax with that of Alopecosa pseudohirta (Schenkel, 1963) from Kansu Province in China revealed that these two are conspecific [Buchar, 2001].

No subsequent study of the type material of Pardosa taczanowski has been undertaken. The type series, consisting of one male and three females [Thorell, 1875b: "marem adultum et feminas paucas" [adult male and a few females]), is shared between the Swedish Museum of Natural History, Stockholm (NHRS) (10'palp, 1 ) ) and the Museum and Institute of Zoology of the Polish Academy of Sciences, Warsaw (MIZW) (1 $\sigma^{7}$ with one palp, 2 우).

The male specimen of $P$. taczanowskii is conspecific with a male of Pardosa chionophila L. Koch, 1879 from the type locality of the latter species [cf. Holm, 1973]. Though the male of $P$. taczanowskii now lacks the characteristic first leg pair, this is described in detail in Thorell's [1875b] extended description: "Tibiae, metatarsi et tarsi pedum I:mi.... evidenter solito crassiores sunt, et aculei subter in tibiis et metatarsi horum pedum brevissimi,..." [Tibiae, metatarsi and tarsi of the first legs... clearly being habitually thick, and spines underneath of tibiae and metatarsi of these legs very short, ...]. Two of the females (in MIZW) are most probably conspecific with the male while the single female (in NHRS) belongs to a species in the $P$. lapponica group (females of some species in this group have very similar epigyne and are hard to identify to species without accompanying males [cf. Marusik et al., 2000]).

While Thorell's description of male $P$. taczanowskii clearly fits that of $P$. chionophila, his description of the 

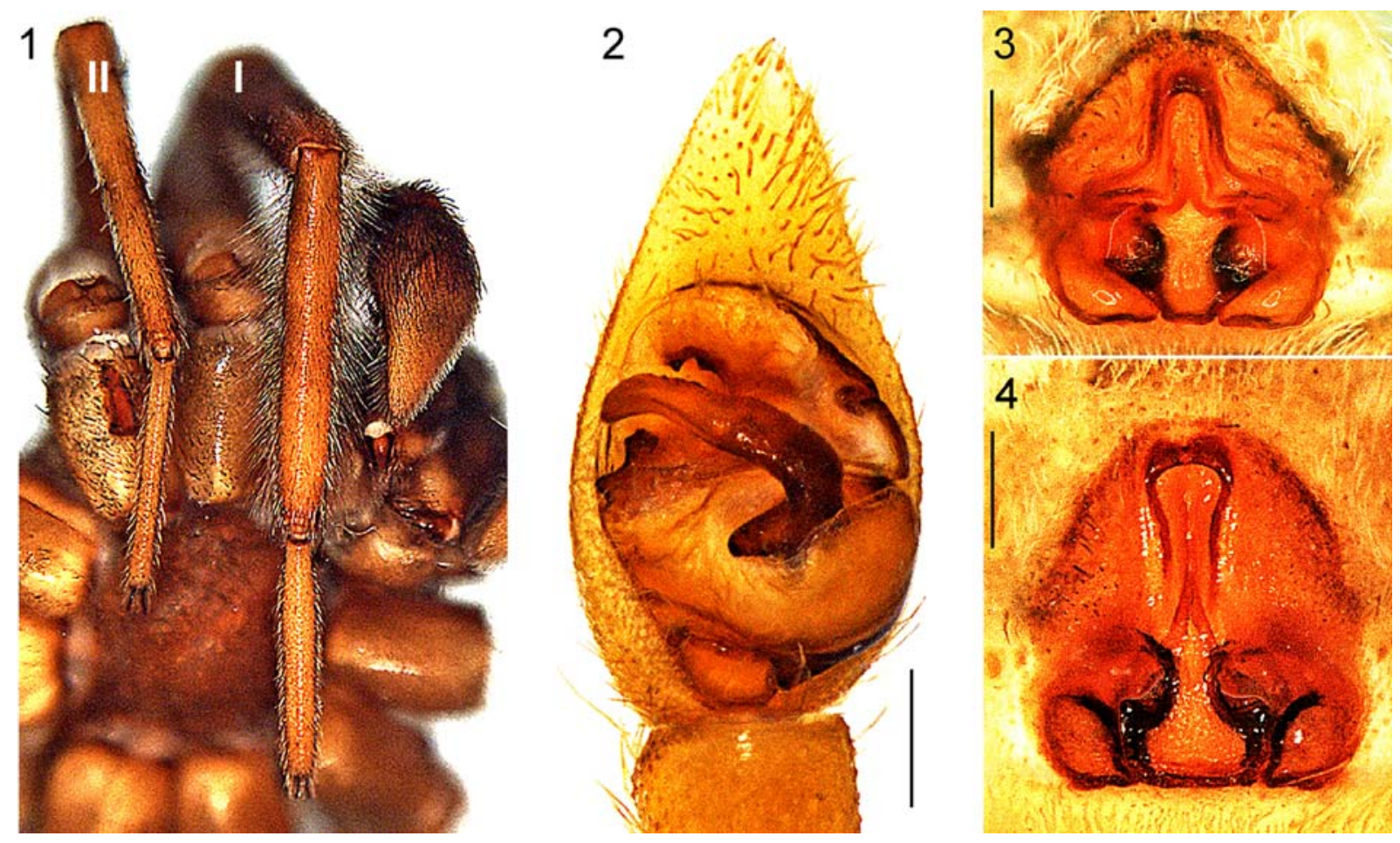

Figs 1-4. Pardosa taczanowskii (Thorell) (1-3): male leg I and II (1), right male palp of lectotype (2), epigyne (3) and Pardosa jeniseica Eskov et Marusik (4), epigyne. Material in Figs 1 and 3 from Russia: Tuva, Uyuk, shore steppe, 4-5 June 1995 (S. Koponen). Material in Fig. 4 from Russia: Irkutsk Area, Baikal'sk, Solzan River, 22 June1977 (Shylenkov). Scale lines $=0.25$ mm.

Pис. 1-4. Pardosa taczanowskii (Thorell) (1-3): нога самца I и II (1); правая пальпа самца, лектотип (2); эпигина (3) и Pardosa jeniseica Eskov et Marusik (4), эпигина. Рис. 1 и 3, экземпляры из Тувы: Уюк, прибрежные степи, 4-5.06.1995 (S. Koponen); pис. 4, экземпляр изИркутской обл., Байкальск, р. Солзан, 22.06.1977 (Шиленков). Масштаб 0,25 мм.

female, though with a rather detailed account of the epigyne, may fit also other species in this species group (the taczanowskii group [cf. Marusik et al., 2000 (sub astrigera group)]. Presently the taczanowskii group encompasses $P$. taczanowskii, $P$. astrigera L. Koch, 1878 and $P$. jeniseica Eskov et Marusik, 1995 but there are also hitherto unrecognized species in this group (Kronestedt, Marusik, unpublished).

Being conspecific with $P$. chionophila, it is plausible that the type material of $P$. taczanowskii was collected somewhere in Siberia or Mongolia and sent to Taczanowski probably by some of the Polish exiles with scientific interests dwelling there because of participating in the anti-Russian 'January uprising' starting in 1863. Kulczyński [1895] mentioned two Polish exiles who collected spiders which were sent to Warsaw: Benedykt Dybowski and Wiktor Godlewski. Dybowski lived in and travelled to different parts of Siberia between 1863 and 1883. He lived for longer periods in Transbaikalia, at times accompanied by among others Godlewski, and participated in expeditions eastwards (Amur area, Sakhalin, Vladivostok) before staying in Kamchatka 1879 1883 [Mlíkovský, 2007]. Though there is no indication about where the type material of $P$. taczanowskii came from, it might have been collected somewhere in Transbaikalia by one of the Polish exiles.
Pardosa chionophila L. Koch cannot be maintained as name for this species due to prevailing usage. The conditions in ICZN Article 23.9.1.1 and 23.9.1.2 are not met with.

\section{Pardosa taczanowskii (Thorell, 1875)}

Figs $1-3$. $\left(\sigma^{\top}+\right)$

Lycosa taczanowskii Thorell, 1875a: 105 (○'); 1875b: 148

Pardosa chionophila L. Koch, 1879: 102, pl. 3 fig. 15 (()) Holm, 1973: 100, figs 86, 88, 90, 91 (O'o); Zyuzin, 1993: fig. 11 ( $\sigma^{T}$ : palea with embolus, conductor and terminal apophysis); Eskov, Marusik, 1995: 66; figs 66, $67\left(0^{7}\right.$ : entire palp and terminal part of bulbus). Syn.n.

Lectotype $\mathrm{O}^{2}$ (lacking one palp and both first legs) of unknown origin (erroneously labeled 'Varsoviæ Taczan') deposited in MIZW, designated here. $O^{7}$-palp of the same specimen deposited in the NHRS (Collectio Thorell No. 247(jar)/1557(tube)). Holotype 9 of P. chionophila from Russia, Krasnoyarsk, deposited in NHRS.

DIAGNOSTIC REMARKS. The species is well described in Holm [1973]. The male is characterized by the first pair of legs having thickened tibia, metatarsus and tarsus (Fig. 1).

In addition, the tibia and metatarsus I have rather short spines, and metatarsus I is covered with a dense pubescence of long thin light hairs, longest pro- and retrolaterally (Fig. 1). A dense pubescence of long thin 
hairs is also present in tibia I (except most proximally). The palp has a tegular apophysis with a long anterior branch directed obliquely retrolaterally, apically turned even more in that direction (Fig. 2) (the tegular apophysis in $P$. astrigera has a similar shape).

The epigyne has a configuration characteristic for the taczanowskii group (Fig. 3). It is not found to be distinguishable from that in, e. g., P. astrigera. Therefore, the identification of females without accompanying males may be uncertain in samples from areas where more species in the taczanowski group co-occur. Females of $P$. jeniseica, however, have a distinct epigyne and are clearly distinguishable. The epigyne depicted as P. jeniseica in Esyunin et al. [1999] belongs to another species (an opinion also expressed in Marusik et al. [2000]). Samples containing both sexes of $P$. jeniseica from different localities in Siberia make clear that the epigyne shown in Fig. 4 belongs to this species.

DISTRIBUTION. Middle Siberia southward to Mongolia [Marusik et al., 2000], also recorded from the Russian Far East [e.g. Kim \& Kurenshchikov, 1995; Omelko, 2010] as well as China [Song et al., 2001]. Marusik et al. [2007] have, however, expressed doubt about the identity of material from the Russian Far East, suggesting that it may belong to a close but undescribed species.

ACKNOWLEDGEMENTS. I am indebted to Dr. Dominika Mierzwa-Szymkowiak, Museum and Institute of Zoology, Polish Academy of Sciences, Warsaw, for loan of material, and to Dr. Yuri M. Marusik, Institute of Biological Problems of the North, Far Eastern Branch of the Russian Academy of Sciences, Magadan, for comparative material and for commenting on the manuscript. I am also grateful to Dr. Kirill Mikhailov for checking previous usage of the name Pardosa (or Lycosa) chionophila.

\section{References}

Buchar J. 2001. Two new species of the genus Alopecosa (Araneae: Lycosidae) from south-eastern Europe // Acta Universitatis Carolinae, Biologica. Vol.45. P.257-266.

Eskov K.Y., Marusik Y.M. 1995.On the spiders from Saur Mt. Range, Eastern Kazakhstan (Arachnida: Araneae) // Beiträge zur Araneologie. Bd.4. P.55-94.
Esyunin S.L., Efimik V.E., Mazura N.S. 1999. Remarks on the Ural spider fauna, 10. New records of spider species (Aranei) // Arthropoda Selecta. Vol.7 (for 1998). No.4. P.319-327.

Holm $\AA$. 1973. On the spiders collected during the Swedish expeditions to Novaya Zemlya and Yenisey in 1875 and 1876 // Zoologica Scripta. Vol.2. No.2-3. P.71-110.

Kim J.P., Kurenshchikov D.K. 1995. Preliminary spiders species list of Khabarovsk Territory Southern Part // Korean Arachnology. Vol.11. No.1. P.55-72.

Kulczyński W. 1895. Attidae musei zoologici Varsoviensis in Siberia orientali collecti // Rozprawy i sprawozdania z posiedzeń wydziału matematyczno-przyrodniczego Akademii umiejetnosci, Kraków. T.32. P.45-98.

Marusik Y.M., Logunov D.V., Koponen S. 2000. Spiders of Tuva, South Siberia. Magadan: Institute for Biological Problems of the North, Russian Academy of Sciences Far East Branch. $252 \mathrm{pp}$.

Marusik Y.M., Tanasevitch A.V., Kurenshchikov D.K., Logunov D.V. 2007. A check-list of the spiders (Araneae) of the Bolshekhekhtsyrski Nature Reserve, Khabarovsk province, the Russian Far East // Acta arachnologica sinica. Vol.16. No.1. P.37-64.

Mlíkovský J. 2007. Types of birds in the collection of the Museum and Institute of Zoology, Polish Academy of Sciences, Warszawa, Poland. Part 2: Asian birds // Journal of the National Museum (Prague), Natural History Series. Vol.176. No.4. P.33-79.

Omelko-Jr. M.M. 2010. [Spatial and altitudinal distribution of the ground dwelling spiders (Arachnida, Aranei) in the southern Primorye by example of Sestra Mountain] // Chteniya pamyati A.I. Kurentsova. Vol.21. P.82-90 [in Russian].

Prószyński J., Staręga W. 1971. Pająki - Aranei // Katalog Fauny Polski. Vol.33. 382 pp.

Prószyński J. 2001. Biographies of Arachnologists. Władysław Taczanowski (1819-1890) // Salticidae: Diagnostic Drawings Library. http://salticidae.org/salticid/diagnost/0-author/ taczanowski.htm

Song D.X., Zhu M.S., Chen J. 2001. The Fauna of Hebei, China: Araneae. Shijiazhuang: Hebei Science Technology Publishing House. 510 pp.

Staręga W. 1983. Wykaz krytyczny pajaków (Aranei) Polski // Fragmenta faunistica. Vol.27. No.11. P.149-268.

Thorell T. 1875a. Diagnoses aranearum Europaearum aliquot novarum // Tijschrift voor Entomologie. Vol.18. P.81-108.

Thorell T. 1875b. Descriptions of several European and NorthAfrican spiders // Kongliga Svenska Vetenskaps-Akademiens Handlingar. Vol.(N.F.)13. No.5. P.1-203.

Wikipedia. 2012. Władysław Taczanowski // http://en.wikipedia.org/ w/index.php?title $=$ W1 $\%$ C $5 \% 82$ adys $\%$ C $5 \% 82$ aw_Taczanowski \&oldid $=522388430$

Zyuzin A.A. 1993. Studies on the wolf spiders (Araneae: Lycosidae). I. A new genus and species from Kazakhstan, with comments on the Lycosinae // Memoirs of the Queensland Museum. Vol.33. Pt.2. P.693-700.

Responsible editor Yu.M. Marusik 